\title{
ARCHAEOLOGICAL AGE ESTIMATION BASED ON OBSIDIAN HYDRATION DATA FOR TWO SOUTHERN ANDEAN SOURCES
}

\author{
ESTIMACIÓN DE EDADES ARQUEOLÓGICAS USANDO \\ LA HIDRATACIÓN DE OBSIDIANAS: DOS FUENTES \\ DE LOS ANDES MERIDIONALES
}

\author{
Raven Garvey ${ }^{1}$, Tim Carpenter ${ }^{2}$, Adolfo Gil ${ }^{3,4,5}$, Gustavo Neme $^{3,4}$ and Robert Bettinger $^{6}$
}

\begin{abstract}
Obsidian is abundant in archaeological sites throughout Mendoza Province, Argentina but no obsidian hydration rates exist to date these assemblages. Direct dating of obsidian artifacts is particularly important in west-central Argentina because the surface record is extensive but well-defined time marker artifacts are lacking. The costs of non-optical hydration dating techniques currently preclude their regular use in the region, however. We present and evaluate 12 models for age estimation based on optical hydration rim measurements for the two most commonly used obsidian types in the region (Las Cargas and Laguna del Maule). Age estimation equations are derived for each source using observed hydration rim-radiocarbon date pairs, and parameterized by variables known to influence obsidian hydration in experimental settings. The equations advanced here are currently best at predicting the known ages of artifacts independently dated by radiocarbon, and can be cautiously used to estimate the ages of obsidian artifacts.
\end{abstract}

Key words: Obsidian hydration, age estimation, Argentina.

Las obsidianas son abundantes en los sitios arqueológicos de la provincia de Mendoza (Argentina). Sin embargo, hasta el momento no existen estimaciones para las tasas de hidratación de estas rocas que puedan utilizarse para fechar esos conjuntos líticos. La realización de fechados directos sobre artefactos de obsidiana resulta particularmente importante para esta región, dado que existe un vasto registro arqueológico de superficie -compuesto principalmente por artefactos líticos-y solo se cuenta con tipos morfológicos cronológicamente sensibles para el Holoceno Tardío. Aquí se presentan y evalúan 12 modelos para estimar las edades de los artefactos de obsidiana basados en la medición óptica de los anillos de hidratación. Específicamente estos modelos fueron desarrollados para las dos obsidianas más comunes en los contextos arqueológicos de la región, procedentes de las fuentes de Las Cargas y Laguna del Maule. Las edades estimadas son derivadas para cada fuente a partir de pares de medición del espesor de la corteza de hidratación-fechado radiocarbono, y calibradas con variables cuya influencia sobre la hidratación ha sido establecida experimentalmente. Las ecuaciones que presentamos son actualmente las que mejor predicen las edades conocidas de artefactos que han sido fechados independientemente por radiocarbono y, por lo tanto, pueden utilizarse con cautela para estimar la antigüedad de los artefactos de obsidiana procedentes de la región.

Palabras claves: hidratación de obsidianas, estimación de edades arqueológicas, Argentina.

While obsidian from a variety of sources (Figure 1) is well represented as tools and debris in archaeological assemblages throughout Mendoza Province, Argentina, obsidian hydration dating has not been previously employed. This is partly because, as in other parts of Andean South America, archaeological attention has historically centered on excavations readily dated by radiocarbon or ceramic typologies (e.g., Eerkens et al. 2008). Debates regarding the efficacy of obsidian hydration dating (e.g., Anovitz et al. 1999; Riddings 1996; Rogers 2006) have further discouraged its use in southern South America even when organics or ceramics are absent. The technique is especially useful for dating surface assemblages, particularly those that, like the Mendozan preceramic (i.e., >2,000 BP),

1 University of Michigan, 4013 Museums, 1109 Geddes Avenue, Ann Arbor, Michigan 48109-1079, U.S.A. garveyr@umich.edu

2 Archaeometrics, 414 Buena Tierra, Woodland, California 95695, U.S.A. tim@archaeometrics.com

3 CONICET-IANIGLA Grupo Vinculado San Rafael, Museo de Historia Natural de San Rafael, Parque Mariano Moreno S/No, (5600) San Rafael, Mendoza, Argentina. agil@mendoza-conicet.gob.ar; gneme@mendoza-conicet.gob.ar

4 UTN Facultad Regional San Rafael/Centro Tecnológico de Desarrollo Regional "Los Reyunos".

5 Facultad de Filosofía y Letras, Universidad Nacional de Cuyo, Mendoza, Argentina.

6 University of California Davis, One Shields Avenue, Davis, California 95616, U.S.A. rlbettinger@ucdavis.edu

Recibido: febrero 2015. Aceptado: octubre 2015.

http://dx.doi.org/10.4067/S0717-73562016005000002. Publicado en línea: 3-febrero-2016. 


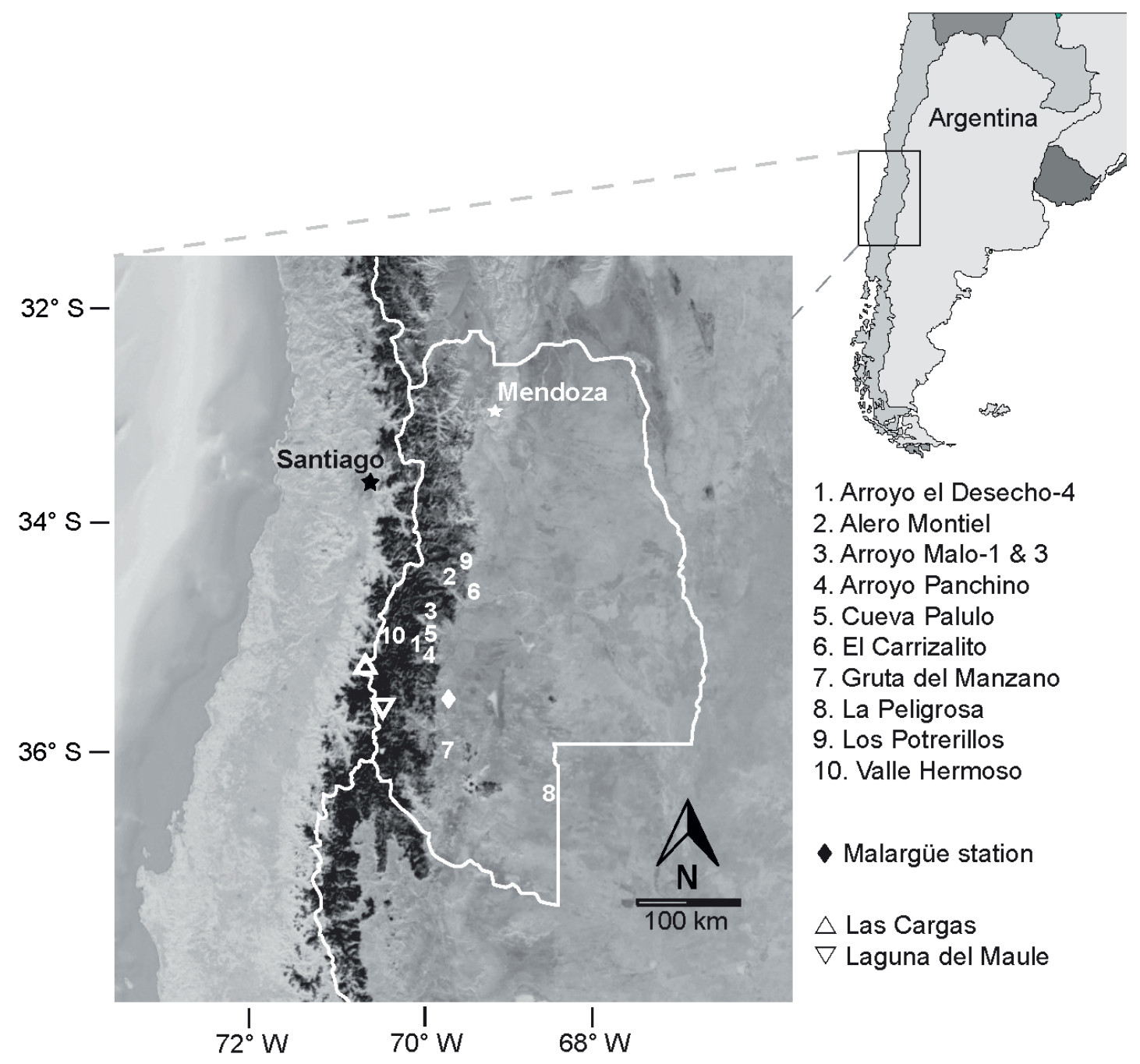

Figure 1. Mendoza Province, Argentina, sites from which OHD samples were drawn for this study, Malargüe Aerodrome (surrogate site for climate data) and obsidian sources Las Cargas and Laguna del Maule.

Provincia de Mendoza, Argentina. Sitios arqueológicos donde se tomaron las muestras de HdO, aeródromo de Malargüe (sitio sustituto para los datos climáticos), y las fuentes de obsidiana Las Cargas y Laguna del Maule.

lack well-defined or accepted lithic time markers. Comprehensive treatment of Mendoza's surface archaeology, however, has itself lagged until recently (Garvey 2012; Neme and Gil 2006), when largescale, regional surface survey demanded a solid chronological basis that obsidian hydration alone could provide. This is the first attempt to estimate the ages of southern Andean obsidian artifacts using hydration, which we present both as a provisional relative dating technique for southern Mendoza and a template for age estimation in other parts of Andean South America where obsidians are abundant and surface records are extensive.
We present pairs of stratigraphically-associated obsidian hydration rim measurements and calibrated radiocarbon dates from 11 sites in western Mendoza to generate a suite of hydration equations for each of the region's two most commonly used obsidian sources, Las Cargas and Laguna del Maule. We compare these source-specific equations to evaluate which best predict the ages of obsidian artifacts independently dated by radiocarbon. Our goal is to identify the best possible, readily accessible means of estimating the ages of archaeological obsidians in west-central Argentina, given the data and resources presently available (Thomas 1981). It is important 
to note that this is not obsidian hydration dating in the usual sense; rather, we merely use obsidian hydration data to obtain age estimates. That is, other techniques (e.g., secondary ion mass spectrometry SIMS) permit more precise dating of obsidians, but their costs currently preclude their regular use in the region.

\section{Background}

In 1960, Friedman and Smith observed that a freshly exposed surface of obsidian takes on ambient water at a knowable rate that can be used to calculate the time elapsed since exposure and, therefore, the date of an obsidian artifact's production (Doremus 1995, 2002; Friedman and Smith 1960; Rogers 2007; Stevenson et al. 1998). Subsequent research has clarified our understanding of the "diffusion-reaction" hydration process (Doremus 2002; Rogers 2008a; cf. Duke and Rogers 2013). We now know, for example, that hydration is affected by temperature in the hydration environment and the intrinsic water content of the obsidian itself (Stevenson and Novak 2011; Stevenson et al. 2013). A variety of methods have been proposed to control for these complications, including analysis of secondary ion mass spectrometry profiles (Liritzis 2014), estimation of the "effective hydration temperature" in an environment (e.g., Rogers 2007; Rogers and Yohe 2011), calculation of source- or flow-specific hydration rates (a means of controlling for intrinsic water content; e.g., Eerkens, Spurling and Gras 2008; Ericson 1975), and estimation of intrinsic water using glass density (Ambrose and Stevenson 2004; Stevenson et al. 2000) or infrared photoacoustic spectroscopy (Stevenson and Novak 2011; Stevenson et al. 2013).

Obsidian should hydrate faster in warmer environments than in cooler ones, and it is important to control for this effect (Friedman and Smith 1960; Rogers and Yohe 2011; Duke and Rogers 2013). Of course, environmental temperature is rarely constant and can fluctuate daily, seasonally, and suprannually. Rogers (2007:657) defines "effective hydration temperature" (EHT) as "a constant temperature that yields the same hydration results as the actual time-varying temperature over the same period," and describes a means of calculating EHT based on diurnal and annual temperature ranges. While such data are best collected using temperature cells buried at the site of interest, they can also be approximated using temperatures measured at a surrogate site, adjusted according to an adiabatic lapse rate. Since temperature also varies with depth below ground surface, the correction factor applied to each observed hydration rim value includes an adjustment for depth (Riddings 1996; Rogers 2007; Rogers and Yohe 2011). However, no known approach accounts for prehistoric conditions; significant, long-term climate changes (e.g., Medieval Warm Period); or temperature histories affected by sediment turbation (see Rogers 2010a; Rogers and Yohe 2011). That is, we have to treat effective hydration temperature as a constant.

Different obsidians may hydrate at different rates in identical environments due to their particular properties, namely intrinsic water content, which must be accounted for prior to age estimation. Direct measures of intrinsic water content are now available, including glass density (Ambrose and Stevenson 2004; Stevenson et al. 2000) and infrared photoacoustic spectroscopy (Stevenson and Novak 2011; Stevenson et al. 2013). These techniques are not yet widely used in archaeology, and anhydrous glass chemistry is a common alternative means of controlling for inherent differences by grouping sources/flows based on physical or, preferably, geochemical properties (as determined by X-ray fluorescence spectroscopy or neutron activation analysis, for example; Bettinger 1989; Eerkens, Spurling and Gras 2008; Ericson 1989; Liritzis 2006). Anhydrous glass chemistry should be used cautiously, however, since intrinsic water content has been shown to vary considerably even within flows (Stevenson et al. 1993).

Two methods are currently available for measuring the depth to which molecular water has penetrated an artifact's surface: (1) measure the visible hydrated zone using optical microscopy (e.g., Eerkens et al. 2008; Friedman and Smith 1960), and (2) measure hydrogen depth profiles via secondary ion mass spectrometry (SIMS; Anovitz et al. 1999; 2008; Liritzis and Diakostamatiou 2002; Liritzis et al. 2004; Stevenson et al. 2004; Stevenson and Rogers 2014). SIMS is generally considered a more accurate measurement of diffusion, given both the estimated error associated with optical measurement $( \pm 0.25 \mu \mathrm{m}$; Stevenson et al. 1987; Stevenson and Novak 2011) and confirmation that "water diffusion extends well beyond the optically defined diffusion front" (Stevenson and Novak 2011:1718; Stevenson et al. 2002). However, the 
current cost of SIMS analysis precludes its regular use in southern Mendoza and northern Patagonia; as in the Great Basin of North America, optical measurement remains the preferred technique in Andean South America.

The rate at which water diffuses into glass can be determined by either of two methods: (1) empirically, by assessing the relationship between hydration depth (however it is measured) and the ${ }^{14} \mathrm{C}$ dates with which the measured samples are clearly associated; or (2) by inducing hydration in a laboratory and calculating a hydration rate based on the activation temperature and Arrhenius equation for reaction kinetics (Friedman and Long 1976; Friedman and Trembour 1983; Rogers 2007; Rogers and Duke 2011; Stevenson and Novak 2011; Stevenson and Rogers 2014). Laboratory-induced rates, while potentially more precise and less timeconsuming, have only recently been shown to reliably predict the ages of artifacts independently dated by radiocarbon or other methods (Ambrose and Novak 2012; Rogers and Duke 2011; cf. Anovitz et al. 1999; Rogers 2006). Empirical rates, on the other hand, generally take longer to establish and may be more subject to error, but provide reasonable predictive accuracy within the range of rim readings and radiocarbon ages used to generate the equations (Rogers 2007, 2008, 2010b).

Friedman and Long (1976) proposed that obsidian hydration proceeds as the square root of time and that the time elapsed since an obsidian surface was last exposed could be estimated by the hydration equation

$$
x^{2}=D t
$$

where $x$ is hydration rim thickness measured in microns ( $x$ preferred here to the more common $r$ to avoid confusion with the coefficient of determination, $R^{2}$ ), $D$ is the hydration constant, and $t$ is time in thousands of years, typically measured by radiocarbon (Anovitz et al. 1999; Friedman and Long 1976; Rogers 2007). The hydration constant, $D$, is a function of temperature, and its value must be estimated before obsidian hydration can be used as a chronometer. By the empirical method, one solves for $D$ using hydration rim-radiocarbon date pairs and local temperature data (typically EHT; Rogers 2007). Rearranging the equation, hydration is often described as proceeding at the square root of time,

$$
x=D t^{0.5}
$$

Experimental studies of the physical chemistry of diffusion in the years since Friedman and Long's (1976) paper have substantiated the quadratic relationship between hydration rim thickness and elapsed time (Doremus 2002; Rogers 2008b, 2009; Stevenson et al. 1998; c.f. Anovitz et al. 1999); Rogers asserts "no other form of functional dependence is currently suggested by theory" (2009:10; cf. Liritzis and Laskaris 2011). However, other experiments challenge the square root of time dependence (Anovitz et al. 1999, 2004; 2008; Riciputi et al. 2002), and some indicate that $t^{0.6}$ and $t^{0.7}$ are better statistical fits for experimental samples with varying proportions of intrinsic water (Stevenson et al. 2013). "The diffusion of water is a complex and dynamic process" and the standard, constant model of diffusion $\left(t^{0.5}\right)$ "may not be the best descriptor of the hydration process" (Stevenson et al. 2013:3021). Alternatively, some analysts choose to treat the exponent empirically, solving for $n$-where hydration proceeds at $t^{n}$ - as the "best fit regression coefficient from the experimental data" (Stevenson and Novak 2011:1717).

In light of this debate, but tangent to its resolution, we propose a regression-based exploratory approach to archaeological age estimation using obsidian hydration data. The Methods section describes the selection and comparison of 12 models that differ with respect to functional dependence and are parameterized by variables known to influence obsidian hydration in experimental settings to identify the rate that best predicts known ages of west-central Argentine obsidian artifacts.

\section{Sample}

As part of a region-wide attempt to characterize obsidian sources and distributions of their respective materials, 490 obsidian specimens from archaeological sites in the study area were assigned to known sources by X-ray fluorescence spectroscopy (XRF). Of these, the majority is from two sources: Las Cargas (65 percent) and Laguna del Maule (22 percent; Figure 1; Garvey 2012), a result consistent with a larger study recently published by Giesso et al. (2011; see also Salgán et al. 2012, 2014). There are presently too few archaeological specimens in our sample from any of the other four known sources in the region (Laguna del Diamante, 
n=0; Payún Matrú, $\mathrm{n}=0$; cerro El Peceño, $\mathrm{n}=3$; and cerro Huenul, $n=7$ ) to calculate even preliminary empirical hydration rates.

Prior to this project, obsidian hydration dating (OHD) had not been applied in west-central Argentina. The sample used here to generate an equation for age estimation of obsidian from Las Cargas consists of 44 hydration rim-radiocarbon date pairs derived from 10 archaeological sites (Table 1); others of the specimens assigned by XRF to the Las Cargas source are not associated with radiocarbon dates. AMS and standard radiocarbon dates were calibrated using OxCal 4.2 (ShCal13 curve; Hogg et al. 2013). We acknowledge that calibrations can be associated with irregular probability densities and note that we have used the mean date within the $95 \%$ confidence interval rather than the mean of all possible dates.

Few of the artifacts selected for this project were point-provenienced during excavation and in most cases the radiocarbon association is by excavation level. To identify erroneous rim-date pairs, multiple obsidian specimens were selected from each radiocarbon dated excavation level whenever possible. Rim thickness measurements of Las Cargas specimens from levels radiocarbon

Table 1. Archaeological sites used in this study, their respective elevations, the number of hydration samples from each source selected from each site, and their associated uncalibrated and calibrated radiocarbon dates. $\mathrm{N}$ (range) = number of hydration samples associated with a particular date, followed by hydration rim range in parentheses; RCY = uncalibrated years before present and one standard deviation from the mean; Cal BC/AD = calibrated radiocarbon years BC/AD as calculated using

OxCal 4.2 (ShCal13 curve, Hogg et al. 2013). The three dates listed are, from left to right, the oldest, mean (in parentheses), and youngest dates associated with the $95 \%$ confidence interval around the radiocarbon mean.

Sitios arqueológicos considerados en este estudio, sus elevaciones, el número de muestras de cada fuente seleccionadas

de cada sitio y sus fechas radiocarbónicas asociadas ( $\sin$ calibrar y calibradas). $N$ (rango) = número de muestras de hidratación asociadas a una fecha determinada, seguido por el rango de cortezas de hidratación entre paréntesis; $R C Y=a \tilde{n} o s$ radiocarbónicos antes del presente sin calibrar y una desviación estándar; cal a.C./d.C. = años radiocarbónicos calibrados a través de OxCal 4,2 (curva de ShCal13, Hogg et al. 2013). Las tres fechas enumeradas son, de izquierda a derecha, mayor, media (entre paréntesis) y menor asociadas con el intervalo de confianza del $95 \%$ alrededor de la media de radiocarbono.

\begin{tabular}{|c|c|c|c|c|c|}
\hline Site & masl & Source & $\mathrm{N}$ (range) & $\mathrm{RCY}$ & $\mathrm{Cal} \mathrm{BC} / \mathrm{AD}$ \\
\hline \multirow[t]{4}{*}{ AD4 } & 2000 & Cargas & $6(1.63-3.0)$ & $5547 \pm 42$ & 4452 (4358) $4261 \mathrm{BC}$ \\
\hline & & Cargas & $4(2.04-2.7)$ & $5360 \pm 39$ & $4263(4159) 4001 \mathrm{BC}$ \\
\hline & & Cargas & $3(2.0-2.6)$ & $6283 \pm 42$ & $5316(5187) 5057 \mathrm{BC}$ \\
\hline & & Maule & $1(4.6)$ & $5400 \pm 40$ & 4327 (4190) 4053 BC \\
\hline Alero Montiel-1 & 2100 & Cargas & $2(1.5)$ & $2239 \pm 50$ & 391 (264) 136 BC \\
\hline Arroyo Malo-1 & 2000 & Cargas & $1(1.7)$ & $1560 \pm 66$ & $411(530) 649 \mathrm{AD}$ \\
\hline \multirow[t]{3}{*}{ Arroyo Malo-3 } & 2000 & Cargas & $1(1.7)$ & $2200 \pm 50$ & 363 (216) $68 \mathrm{BC}$ \\
\hline & & Cargas & $1(2.9)$ & $3570 \pm 40$ & 2009 (1855) $1701 \mathrm{BC}$ \\
\hline & & Cargas & $1(3.2)$ & $3810 \pm 100$ & 2472 (2198) 1924 BC \\
\hline \multirow[t]{2}{*}{ Arroyo Panchino } & 2200 & Cargas & $1(2.0)$ & $2793 \pm 39$ & 998 (907) 815 BC \\
\hline & & Maule & $1(2.0)$ & $1048 \pm 36$ & 986 (1018) $1149 \mathrm{AD}$ \\
\hline \multirow[t]{3}{*}{ Cueva Palulo } & 2500 & Cargas & $1(1.5)$ & $2042 \pm 37$ & $99 \mathrm{BC}(4 \mathrm{AD}) 107 \mathrm{AD}$ \\
\hline & & Cargas & $1(1.5)$ & $2228 \pm 37$ & 373 (258) $143 \mathrm{BC}$ \\
\hline & & Cargas & $1(1.5)$ & $2793 \pm 39$ & 998 (907) 815 BC \\
\hline El Carrizalito & 2200 & Cargas & $1(1.2)$ & $2332 \pm 35$ & $411(311) 211 \mathrm{BC}$ \\
\hline \multirow[t]{8}{*}{ El Manzano } & 1350 & Cargas & $2(3.6-4.0)$ & $7070 \pm 170$ & 6241 (5931) $5620 \mathrm{BC}$ \\
\hline & & Cargas & $1(4.0)$ & $7110 \pm 180$ & $6352(5991) 5630 \mathrm{BC}$ \\
\hline & & Cargas & $1(4.0)$ & $7330 \pm 150$ & 6451 (6169) $5886 \mathrm{BC}$ \\
\hline & & Maule & $10(2.0-4.0)$ & $1300 \pm 50$ & 671 (779) $886 \mathrm{AD}$ \\
\hline & & Maule & $12(2.0-4.4)$ & $2100 \pm 70$ & $354 \mathrm{BC}(122 \mathrm{BC}) 110 \mathrm{AD}$ \\
\hline & & Maule & $2(8.6-8.7)$ & $7070 \pm 170$ & 6241 (5931) $5620 \mathrm{BC}$ \\
\hline & & Maule & $3(8.0-8.3)$ & $7110 \pm 180$ & $6352(5991) 5630 \mathrm{BC}$ \\
\hline & & Maule & $4(7.0-9.4)$ & $7190 \pm 130$ & 6339 (6039) $5738 \mathrm{BC}$ \\
\hline La Peligrosa & 900 & Maule & $3(2.2-3.0)$ & $400 \pm 70$ & $1432(1543) 1653 \mathrm{AD}$ \\
\hline Los Potrerillos & 2200 & Cargas & $3(1.2-2.8)$ & $3610 \pm 100$ & $2201(1930) 1658$ BC \\
\hline \multirow[t]{2}{*}{ Valle Hermoso } & 2800 & Cargas & $7(1.2-1.9)$ & $1410 \pm 60$ & $548(694) 839 \mathrm{AD}$ \\
\hline & & Cargas & $6(1.0-1.9)$ & $1950 \pm 50$ & $46 \mathrm{BC}(88 \mathrm{AD}) 222 \mathrm{AD}$ \\
\hline
\end{tabular}


dated between $1,410 \pm 60 \mathrm{BP}(570-775 \mathrm{Cal} \mathrm{AD})$ and 7,330 $\pm 150 \mathrm{BP}(5,886-6,451 \mathrm{Cal} \mathrm{BC})$ range from 0.97 to 4.0 microns $(\mu \mathrm{m})$.

The sample used to generate an equation for age estimation of obsidian from Laguna del Maule consists of 36 hydration rim-radiocarbon date pairs derived from four archaeological sites (Table 1); others of the specimens assigned to the Laguna del Maule source are not associated with radiocarbon dates. As with the Las Cargas sample, associations with radiocarbon-dated materials are by excavation level so multiple specimens were drawn from individual radiocarbon-dated levels whenever possible. Rim thickness measurements on Laguna del Maule specimens from levels radiocarbon dated between $400 \pm 70 \mathrm{BP}(1,432-1,653 \mathrm{Cal} \mathrm{AD})$ and $7,190 \pm 130 \mathrm{BP}(5,738-6,257 \mathrm{Cal} \mathrm{BC})$ range from 1.6 to $9.4 \mu \mathrm{m}$.

In the southern Andes, daily and annual temperatures vary with elevation. Eleven sites from a range of elevations between 900 and 2,800 meters above sea level were selected to assess the effects of temperature on hydration (Figure 1). Table 1 presents the sites selected for this study, their respective elevations, and the obsidian types present at each.

\section{Methods}

\section{X-ray fluorescence}

Granting that intrinsic water content can vary considerably within sources (Stevenson et al. 1993), each sample was assigned to a source group based on its geochemical composition in a first-order attempt to control for the effects of intrinsic water on hydration rate. Geochemical composition was determined by a Bruker hand-held energy-dispersive XRF spectrometer (EDXRF), calibrated using "well-characterized source samples in the MURR reference collection... previously analyzed by NAA and XRF in several laboratories to establish consensus values" (Glascock and Ferguson 2009:3). MURRAP Statistical Routines (v. 8.4) and GAUSS Runtime (v. 8.0) spectral analysis packages compared the peak element concentrations of the sample specimens to those of the region's known sources to determine each sample's most likely source (Garvey 2012; Giesso et al. 2011; Glascock and Ferguson 2009). All subsequent analyses were source specific.

\section{Obsidian hydration rim measurement}

To measure the hydration rim thicknesses of the samples considered in this study, two parallel cuts were made on the appropriate portion of the specimen using a lapidary saw mounted with two four-inch diameter, diamond-impregnated .004" blades. Samples were extracted and mounted with Lakeside thermoplastic cement onto sequentially numbered microscope slides and manually ground to between 30 and $50 \mu \mathrm{m}$ thick.

The prepared slides were viewed under a Meiji petrographic microscope fitted with a Lasico digital filar eyepiece. Once a well-defined hydration rim was observed on a color monitor screen communicating directly with the microscope, the hydration rim was centered on the monitor to reduce parallax and measured with the micrometer. Typically, ten measurements were taken on each specimen but, occasionally, imperfections in the stone, weathering or surface damage caused by the saw or grinding process, permitted as few as three measurements per specimen. Hydration values were recorded to the nearest $0.01 \mu \mathrm{m}$ and the mean and standard deviation of rim thickness were computed for each specimen.

\section{EHT calculation}

Rogers (2007) provides a series of equations for modeling obsidian hydration according to effective hydration temperature. EHT is a function of average annual temperature, annual and diurnal temperature ranges and temperature change with depth below ground surface. To estimate an archaeological context's EHT without the aid of a buried temperature cell, Rogers (2007) recommends calculating EHT using temperature data from a surrogate site for which there are at least 10 years of recorded daily maximum and minimum temperatures, and an adiabatic lapse rate of $-1.9^{\circ} \mathrm{C}$ per thousand-foot $(\sim 305$ $\mathrm{m})$ increase in elevation. Here, EHT is calculated using this estimate of average annual temperature:

$$
T_{a}=T_{a s}-1.9 *\left(H-H_{s}\right)
$$

where $T_{a s}$ is the average annual temperature at the surrogate site, $H$ is elevation of site of interest (thousands of feet above sea level), and $H_{s}$ is the surrogate site's elevation (Rogers 2007). In this study, Malargüe Aerodrome meteorological station 
$\left(1,426\right.$ meters $\left(4,678^{\prime}\right)$ above sea level; Figure 1$)$ served as the surrogate site and archaeological EHTs were calculated using a $-1.9^{\circ} \mathrm{C}$ adiabatic lapse rate per 1,000' $(\sim 305 \mathrm{~m})$ increase in elevation from Malargüe Aerodrome.

To incorporate EHT into hydration rate models, each hydration rim measurement should be "corrected" to reflect that sample's particular EHT. EHTs for the samples in this study are between $10-20^{\circ} \mathrm{C}$ so each sample's rim correction factor $(\mathrm{RCF})$ is calculated by the equation

$$
\mathrm{RCF}=\exp \left(-0.06 * \Delta T_{e}\right)
$$

where $\Delta T_{\rho}$ equals the difference between the sample's EHT and EHT at the surrogate site (Rogers 2007:659). Each measured rim value is multiplied by its own $\mathrm{RCF}$ and the corrected rim values and corresponding radiocarbon dates are used to calculate a sourcespecific hydration rate (Rogers 2007).

\section{Rate model formulation and comparison}

A total of 12 models were derived from observed hydration rim-radiocarbon date pairs and parameterized by variables known to influence obsidian hydration in experimental settings. Models are of two basic forms -quadratic and linear-and otherwise vary with respect to correction for EHT, including the origin as data point, and forcing regression through the origin. Table 2 lists the model parameters; empirically derived, source-specific models are presented in the following section.

Table 2. Descriptions of the 12 hydration models compared in this study. Subsequent tables refer to this lettering system.

Descripciones de los 12 modelos de hidratación comparados en este estudio. Tablas siguientes se refieren a este sistema de rotulación.

\begin{tabular}{ll}
\hline A & linear, uncorrected rims $(x=D t)$ \\
B & same as A, regressed through the origin \\
C & same as A, origin included as a data point \\
D & linear, EHT-corrected rims $(x=D t)$ \\
E & same as D, regressed through the origin \\
F & same as D, origin included as a data point \\
G & quadratic, uncorrected rims $\left(x^{2}=D t\right)$ \\
H & same as G, regressed through the origin \\
I & same as G, origin included as a data point \\
J & quadratic, EHT-corrected rims $\left(x^{2}=D t\right)$ \\
K & same as J, regressed through the origin \\
L & same as J, origin included as a data point \\
\hline
\end{tabular}

Early work with empirically-derived hydration rates in the western United States (e.g., Bettinger 1989; Garfinkel 1980; Hall 1983; Hughes 1984, 1989; Meighan 1978, 1983) showed that, when data are few, linear rates are sometimes more accurate predictors of known artifact ages than quadratic ones. While linear models contradict the physical chemistry of diffusion, that is not at issue here. Archaeological use of obsidian is not an experiment in physical chemistry. It is predicated solely on the need for the best direct estimator of artifact age. To obtain this requires evaluating the relative predictive power of a variety of models to identify the best estimator of artifact age, regardless of its fit with theory. Proponents of empirical rate derivation have long understood that their rates are provisional and require reassessment as more data become available.

In addition to testing alternative algorithms, exploratory model fitting should test the effects of other common practices, most notably those of treating the origin as a data point (zero hydration rim at time zero) and forcing regression through the origin (RTO). When empirically derived rates are based on datasets that begin some distance from the origin, for example, RTO may diminish data-to-model fit (Eisenhaur 2003; Hocking 1996) because it nearly always changes the sum of least squares or "best fit" slope of the line (arc of the curve). As demonstrated empirically below using data from west-central Argentina, within the range of rim values used to calculate rates, models with forced regression lines routinely perform worse than models not so forced. More generally, any empirical hydration rate is likely to be less accurate beyond either end of the range of rim thicknesses used to calculate it. A model that predicts ages better within a narrower range of rim values may be preferable to one that predicts less well across a wider range.

Models are compared using two statistics, the coefficient of determination $\left(R^{2}\right)$ and root-meansquare error of the regression line (RMSE), each calculated using observed and predicted dates associated with each rim measurement to gauge models' respective predictive power.

Less commonly used in archaeology than $R^{2}$, RMSE is a measure of the overall magnitude of prediction errors (residuals) that can be compared across models to gauge their relative accuracy. Generally, the reliability of empirically derived hydration equations increases (larger $R^{2}$, smaller 
RMSE) with the number of hydration rim-radiocarbon date pairs used to generate the equation, and equations must be reevaluated and revised as new pairs become available.

\section{Provisional Hydration Rates for Two Southern Andean Obsidians}

\section{Las Cargas}

Of the 12 hydration models compared for Las Cargas obsidian (Table 3), Model A -the unconstrained linear equation based on rim values uncorrected for temperature and excluding the origin as a data point- is best at predicting known radiocarbon ages $\left(R^{2}=0.6\right.$; $\mathrm{RMSE}=1519$ years $)$. Model A is

$$
t=2201.3 x-422.17
$$

where $t$ is radiocarbon years before present and $x$ is hydration rim thickness in microns. Models B (RTO linear, uncorrected rims) and C (unconstrained linear, including origin as data point) performed virtually as well, and all three equations predict dates within a few hundred years of the mean calibrated date $\mathrm{BC}$ for the largest rim measurement presently associated with a radiocarbon date $(4.02 \mu \mathrm{m}=7,070$ $\pm 170 \mathrm{BP}=7,945$ calendar years ago, mean of $95 \%$ confidence interval range; A overpredicts by 482 years, B by 190 , and C by 443).

The $R^{2}$ and RMSE values in Table 3 indicate that equations based on temperature-corrected rim values perform worse than those uncorrected. Interestingly, when the Las Cargas samples are grouped by elevation and used to calculate elevation-specific hydration rates, the observed trend contradicts the expectation: Collections from higher elevations appear to hydrate faster than those from lower elevations (Figure 2). Available data are presently insufficient to determine whether this is the result of an inappropriate surrogate site or adiabatic lapse rate, or whether temperature simply does not affect hydration over the range of elevations considered in this study.

Among the six models that do not correct for temperature, linear models consistently outperform quadratic ones. Analysis of the residuals suggests that this is due in part to the tendency of the quadratic equations to under-predict age at the low end of the distribution and over-predict age at the high end of the available sample. Beyond the range of rim values used to calculate the rates compared here, that is, for hydration rims larger than $4 \mu \mathrm{m}$, quadratic models predict radiocarbon ages at or beyond the accepted date of initial occupation of the area (ca. 11,000 BP, ca. 12,900 calendar years ago) and, for the largest known rim value for Las Cargas obsidians $(6.01 \mu \mathrm{m})$, ages much older than accepted dates for human colonization of the New World (Table 3).

Three lines of evidence suggest that Las Cargas obsidian hydrates slowly. First, models based on available rim-radiocarbon pairs indicate that $4 \mu \mathrm{m}$ of hydration equal between ca. 7,100 and 10,600 calendar years, which is slow relative to other well-documented obsidian sources in the northern and southern hemispheres (e.g., Coso in California, Rogers 2009; southern Peru, Eerkens et al. 2008). Second, a distinctive projectile point form associated with early archaeological components has a maximum rim value of $4.1 \mu \mathrm{m}$ when made on Las Cargas obsidian and a maximum rim value of 12.2 when made on Laguna del Maule obsidian (Garvey 2012). The dates calculated for these rim values by each source's best preliminary equation are, respectively, $\sim 8,400$ and $\sim 13,200$ calendar years ago, which roughly correspond to the earliest human occupations in southern Mendoza (e.g., 12,770-12,020 calendar years ago; Gil et al. 2005; Neme and Gil 2012). Third, no obsidian sample -whether from an archaeological context or collected during a recent trip to the Las Cargas source- has a rim value larger than $6.1 \mu \mathrm{m}$ (Salgán et al. 2015). Model A in Table 3, currently the best predictor of radiocarbon ages, generates a date of $\sim 12,800$ calendar years ago for the $6.1 \mu \mathrm{m}$ rim measurement (no associated radiocarbon date), which is consistent with the accepted date of earliest occupation in southern Mendoza. These observations further highlight the present predictive superiority of linear models; for all rim values of $5 \mu \mathrm{m}$ and above, quadratic equations predict unrealistically old ages (e.g., $6.1 \mu \mathrm{m}$ equals between $\sim 17,000$ and $\sim 24,000$ calendar years ago; Table 3).

Slow hydration of Las Cargas obsidian may explain both the relatively low predictive power of all models presented here and the present superiority of linear models. The more slowly hydration proceeds, the more time is represented by each micron of hydrated rim (e.g., Las Cargas $\approx 2,200$ years per micron; Laguna del Maule $\approx 1,200$ years 


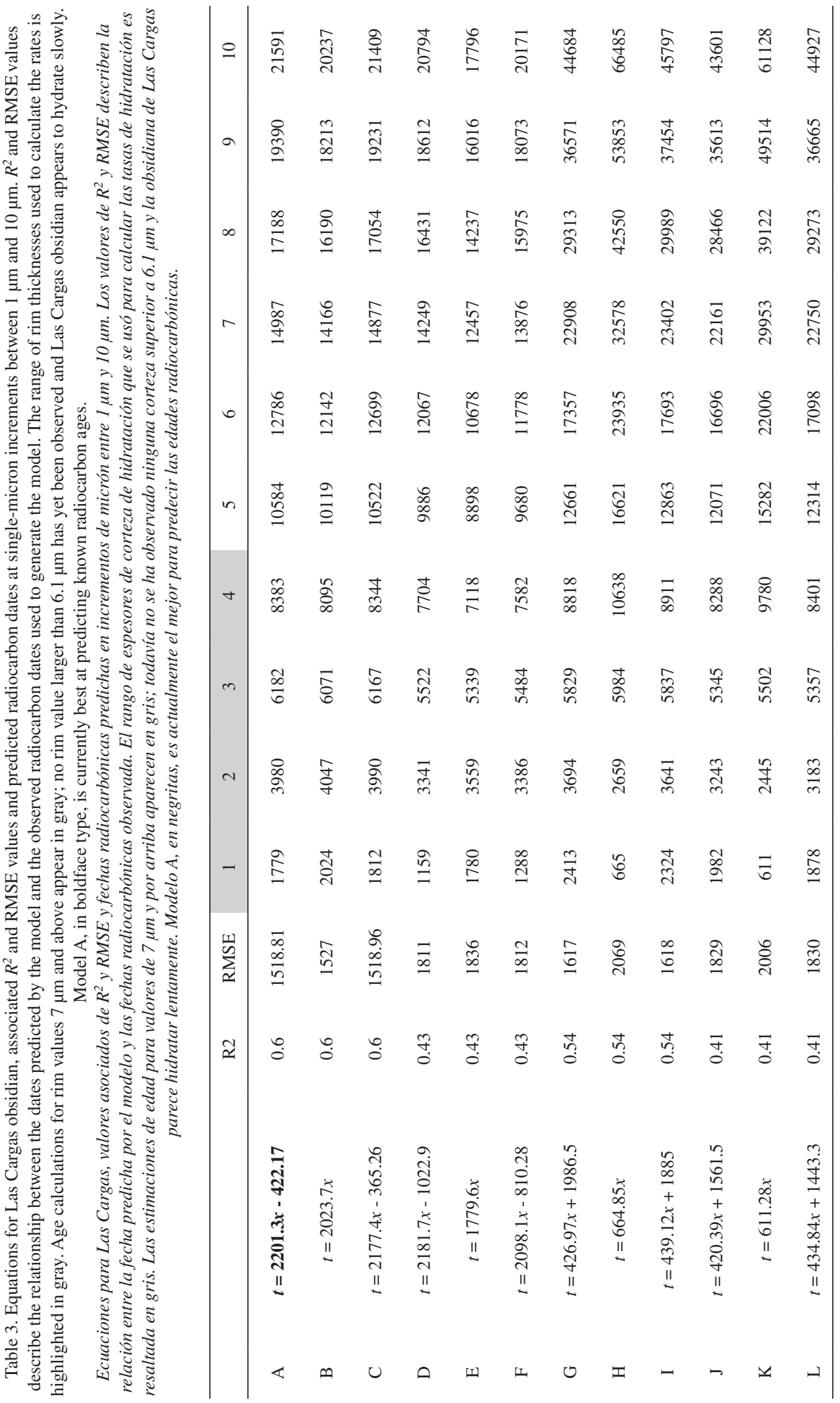




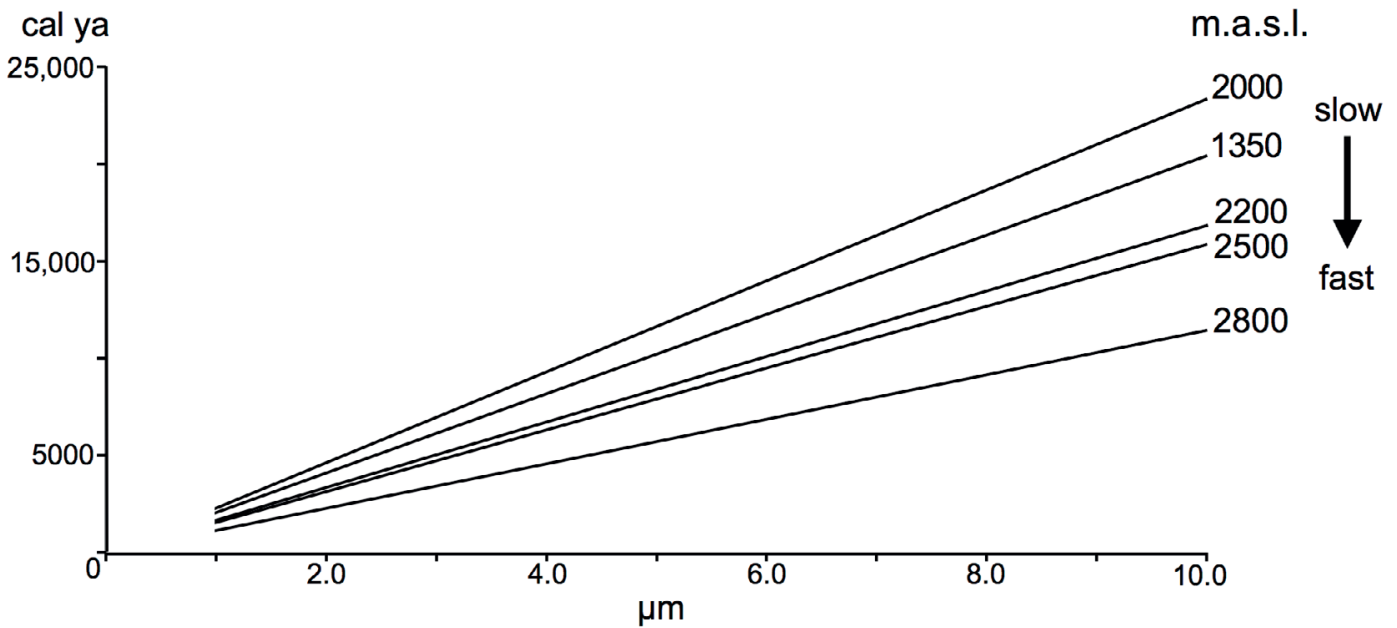

Figure 2. Apparent relative rate of hydration at different elevations (meters above sea level) based on observed relationships between OHD - radiocarbon pairs at each elevation.

Velocidad relativa aparente de la hidratación a elevaciones distintas (msm) basada en las relaciones observadas entre pares HdO - radiocarbono a cada elevación.

per micron). In the available sample of Las Cargas obsidian, the majority of rim values (84 percent) fall between 1 and $3 \mu \mathrm{m}$, within which narrow range there are several clusters of very similar rim values (e.g., around 1.2, 1.5 and $2.2 \mu \mathrm{m}$ ). Models for this material type will be significantly improved by both a greater variety of rim values between 1 and $3 \mu \mathrm{m}$-to capture more sub-micron variationand a larger sample of hydration rim-radiocarbon pairs from outside this range. A larger sample will also mitigate the potential effects of measurement error, which could disproportionately affect smaller rim values.

Slow hydration of Las Cargas obsidian may also account for the fact that linear models outperform quadratic ones. The quadratic model that best predicts the ages of Las Cargas samples (Model G in Table 3) is well approximated by its tangent line across the range of rim values used to derive the model (Figure 3); Model G is virtually linear between 1 and $4 \mu \mathrm{m}$ on account of slow rim growth. Although Model G's linear approximation is nearly parallel to linear Model A (the model that best predicts ages of Las Cargas samples), Model G accumulates error (i.e., RMSE increases) because the squared term leads to under-prediction of ages associated with very small rim-values and overprediction between $3 \mu \mathrm{m}$ and $4 \mu \mathrm{m}$.

\section{Laguna del Maule}

Of the 12 hydration models compared for Laguna del Maule obsidian (Table 4), the linear equation using temperature-corrected rims -Model D- emerges as the most accurate preliminary predictor of artifact ages $\left(R^{2}=0.94 ;\right.$ RMSE $=712$ years). Model D is

$$
t=1212.4 x-1529.4
$$

where $x$ and $t$ are defined as above. Applying Model D to 68 archaeological samples of Laguna del Maule obsidian (including those not presently associated with radiocarbon dates) indicates that the source was used between approximately 350 and 10,600 calendar years ago, which is consistent with the radiocarbon-dated span of occupation in the region.

Unlike Las Cargas equations, the predictive power of Laguna del Maule equations is generally improved by correcting rim values for EHT. The improvements are slight and inconsistent, however, and the negative effect of temperature correction on Las Cargas models suggests that temperature corrected rates should be used with caution until the discrepancy is resolved. Model A, the uncorrected, 


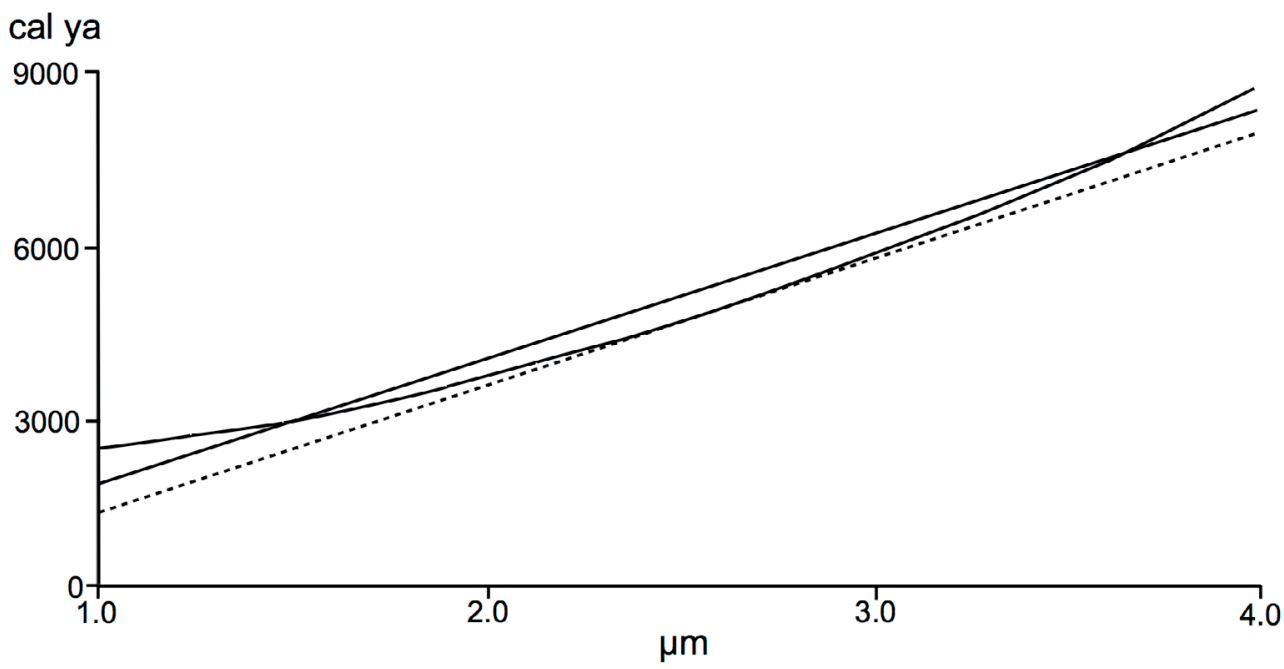

Figure 3. Curve and line associated with Las Cargas Models G (solid line; quadratic, uncorrected rims) and A (solid line; linear, uncorrected rims, origin included as data point), respectively. The dashed line tangent to the curve is the linear approximation of Model G.

Curva y línea, respectivamente, asociadas con modelos Las Cargas G (línea continua; cuadrática, cortezas de hidratación sin corregir) y A (línea continua; lineal, cortezas de hidratación sin corregir, origen incluido como punto de datos). La línea discontinua tangente a la curva es la aproximación lineal del Modelo G.

unconstrained linear rate is reasonably accurate $\left(R^{2}=0.91 ;\right.$ RMSE $\left.=844\right)$ :

$$
t=1143.4 x-1705.5
$$

Similar to Las Cargas, linear models perform better than quadratic ones with Laguna del Maule obsidian, but the difference is less pronounced and the third most accurate model is quadratic using temperature correction (Model J in Table 4). Assessment of quadratic model residuals indicates that there are large discrepancies between predicted and observed radiocarbon ages on samples with rim values above $7 \mu \mathrm{m}$. Addition of paired samples in this range, as they become available, will undoubtedly improve the predictive power of quadratic models, bringing OHD for this source material into line with current diffusion theory.

\section{Discussion and Conclusions}

In this statistical analysis of 12 age estimation models for the two archaeologically most common obsidians in southern Mendoza, linear equations emerged as the best predictors of known radiocarbon dates. This result is obviously inconsistent with the modern understanding of diffusion in glass. We do not propose that southern Mendozan obsidians hydrate at linear rates, only that linear equations are better at predicting artifacts' associated radiocarbon ages within the range of rim values currently available, and that these models should be used cautiously to approximate the ages of archaeological obsidians until more data are available. Again, we stress that this is not obsidian hydration dating in the usual sense; we are merely using obsidian hydration data to obtain age estimates.

That models uncorrected for temperature outperform those so corrected also contradicts modern hydration theory; correcting for effective hydration temperature should improve hydration rates (Rogers 2007), sometimes dramatically (Rogers 2009). However, EHT correction decreased the predictive power of Las Cargas models, and improved Laguna del Maule models only slightly. Use of buried temperature cells or a different surrogate site and adiabatic lapse rate might reveal that temperature does influence hydration across the range of elevations considered in this study. Until then, uncorrected rims should be favored for Las Cargas and possibly Laguna del Maule.

RTO-forcing regression through the origin-did not significantly decrease regression line goodness of fit, but it did consistently increase RMSE, indicating decreased predictive power among RTO models. This effect is more pronounced in the 


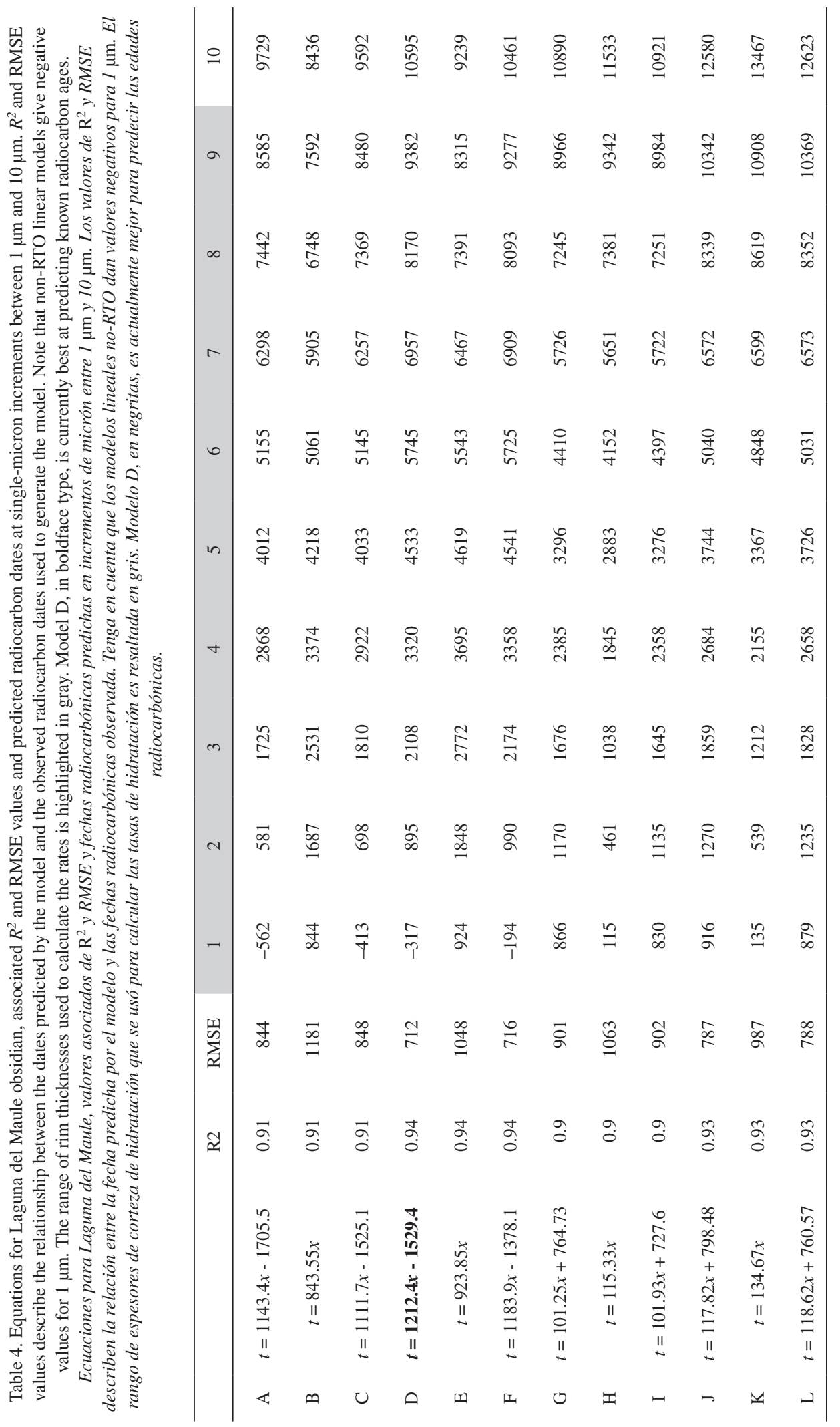


Laguna del Maule samples -among which RTO equations have RMSE values 38 percent larger on average than their non-RTO equivalents- than in the Las Cargas sample (RTO equations have 4 percent larger error on average). Statisticians have demonstrated that when empirically derived rates are based on datasets that begin some distance from the origin, RTO can diminish the model's fit to the data (Eisenhaur 2003; Hocking 1996). The smallest paired rim value in the Laguna del Maule sample is $1.6 \mu \mathrm{m}$ while the smallest in the Las Cargas sample is $0.97 \mu \mathrm{m}$, which may account for the proportional differences mentioned above. Archaeologists interested in developing or using empirically derived obsidian hydration rates should be aware of the potential negative effects of RTO, despite its theoretical justification. More generally, archaeologists should appreciate that any hydration rate is likely to be less accurate outside the range of the rim thickness values used to calculate it.

Likewise, we caution against uncritical inclusion of the origin as a data point. Clearly, rim thickness should be zero at time zero. However, the fact that some studies indicate a distinct initial rate of hydration makes predictions between the origin and the smallest observed rim value suspect (Anovitz et al. 1999; 2008; Broadkey and Liritzis 2004; Crank 1975). In the present study, including the origin as a data point has mixed results. In the Las Cargas case, linear models that include the origin have slightly higher $R^{2}$ values $(0.06$ increase on average) and negligibly lower RMSE values (0.62-year decrease on average); quadratic models are slightly improved by inclusion of the origin (0.02 increase in average $R^{2} ; 1$-year increase in RMSE on average). All Laguna del Maule models perform slightly worse when the origin is included (RMSE values increase) and inclusion of the origin invariably predicts non-zero ages for rim values of zero.

Empirical rates improve as the database of paired hydration rim-radiocarbon dates grows, a statistical truism confirmed by nearly half a century of obsidian hydration studies in the western United States. The age estimation equations presented here are provisional, intended as a first-order analysis of the relationship between hydration rim thickness and artifact age among two common southern Mendozan obsidians. The equations should be adjusted as more hydration rim-radiocarbon pairs and relevant data (e.g., within-source variations in intrinsic water content) become available, and additional models should be assessed as our understanding of the hydration process improves.

Archaeologists develop and use obsidian hydration rates to place objects and events in time-as Thomas (1981) put it, to predict radiocarbon dates. The last several decades have seen tremendous advances in glass science, but the cost of non-optical hydration dating techniques currently precludes their regular use in west-central Argentina, making the empirical method most tenable. While there is good reason to think that well attested empirical hydration rates will conform to hydration theory, the unconventional provisional age estimation equations presented here offer a transparent means of relative dating and should be used cautiously to estimate the ages of archaeological obsidians in Argentina until funding and access to instrumentation are available to improve their precision.

Acknowledgments: We thank Alexander Rogers and Jelmer Eerkens for thoughtful feedback on earlier versions of this paper, and Michael Glascock and Jeff Ferguson for their help with the sourcing analysis including contracted analyses subsidized by National Science Foundation grant \#0802757. Research abroad (RG), obsidian hydration and X-ray fluorescence analyses were funded (to RG) by the J. William Fulbright Foundation, National Science Foundation (BCS-0914578), Hemispheric Institute for the Americas and the following University of California, Davis divisions: Department of Anthropology, Office of Graduate Studies, Consortium for Women and Research and Institute of Government Affairs. Permission to study archaeological collections was kindly granted by the Museo de Historia Natural, San Rafael, Argentina. The fieldwork that generated the collections and radiocarbon dates was funded (to AG and GN) by the Consejo Nacional de Investigaciones Científicas y Técnicas and Agencia Nacional de Promoción Científica y Tecnológica (PICT 20121015); we thank Miguel Giardina, Clara Otaola, Leonardo Paulides, Laura Salgán and Fernando Franchetti for their assistance in fieldwork. Karen Borrazzo helped with the Spanish abstract. We also thank the four anonymous reviewers whose comments improved this paper. 


\section{References Cited}

Ambrose, W. and S. Novak 2012. Obsidian hydration chronometrics using SIMS and optical methods from 26-year temperature controlled exposures. In Obsidian and Ancient Manufactured Glasses, edited by I. Liritzis and C. Stevenson, pp. 15-25. University of New Mexico Press, Albuquerque.

Ambrose, W. and C. Stevenson 2004. Obsidian density, connate water and hydration dating. Mediterranean Archaeology and Archaeometry 4:5-16.

Anovitz, L., D. Cole, and M. Fayek 2008. Mechanisms of rhyolitic glass hydration below the glass transition. American Mineralogist 93:1166-1178.

Anovitz, L., M. Elam, L. Riciputi, and D. Cole 1999. The failure of obsidian hydration dating: sources, implications and new directions. Journal of Archaeological Science 26:735-752.

Anovitz, L., M. Elam, L. Riciputi, and D. Cole 2004. Isothermal time-series determination of the rate of diffusion of water in Pachuca obsidian. Archaeometry 46:301-326.

Bettinger, R. 1989. Establishing an hydration rate for Fish Springs obsidian. In Current Directions in California Obsidian Studies, edited by R. Hughes, pp. 59-68. University of California Archaeological Research Facility, Berkeley.

Broadkey, R. and I. Liritzis 2004. The dating of Obsidian: A possible application for transport phenomena (a tutorial). Mediterranean Archaeology and Archaeometry 4:67-82.

Crank, J. 1975. The Mathematics of Diffusion. $2^{\text {nd }}$ ed. Clarendon Press, Oxford.

Doremus, R. 1995. Diffusion of water in glass. Journal of Materials Research 10:2379-2389.

Doremus, R. 2002. Diffusion of Reactive Molecules in Solids and Melts. Willey Interscience, New York.

Duke, D. and A. Rogers 2013. Does an obsidian hydration rim care when temperature fluctuation occurs? International Association for Obsidian Studies Bulletin 49:8-16.

Eerkens, J., A. Spurling, and M. Gras 2008. Measuring prehistoric mobility strategies based on obsidian geochemical and technological signatures in the Owens Valley, California. Journal of Archaeological Science 35:668-680.

Eerkens, J., K. Vaughn, T. Carpenter, C. Conlee, M. Linares Grados, and K. Schreiber 2008. Obsidian hydration dating on the South Coast of Peru. Journal of Archaeological Science 35:2231-2239.

Eisenhaur, J. 2003. Regression through the origin. Teaching Statistics 25:76-80.

Ericson, J. 1975. New results in obsidian hydration dating. World Archaeology 7:151-159.

Ericson, J. 1989. Toward flow-specific obsidian hydration rates: Coso Volcanic Field, Inyo County, California. In Current Directions in California Obsidian Studies, edited by R. Hughes, pp. 13-22. University of California Archaeological Research Facility, Berkeley.

Friedman, I. and W. Long 1976. Hydration rate of obsidian. Science 191:347-352.
Friedman, I. and R. Smith 1960. A new dating method using obsidian: Part I, the development of the method. American Antiquity 25:476-522.

Friedman, I. and F. Trembour 1983. Obsidian hydration dating update. American Antiquity 48:544-547.

Garfinkel, A. 1980. An Initial Archaeological Evaluation of CA-Iny-2146, Inyo County, California. Report on file, California Department of Transportation.

Garvey, R. 2012. Human Behavioral Responses to Middle Holocene Climate Changes in Northern Argentine Patagonia. Ph.D. dissertation, Department of Anthropology, University of California, Davis.

Giesso, M., V. Durán, G. Neme, M. Glascock, V. Cortegoso, A. Gil, and L. Sanhueza 2011. A study of obsidian source usage in the Central Andes of Argentina and Chile. Archaeometry 53:1-21.

Gil, A. and G. Neme 2006. Distribuciones arqueológicas superficiales en Payunia-Llancanelo. In Arqueología y Ambiente de Áreas Naturales Protegidas de la Provincia de Mendoza. Número Especial Anales de Arqueología y Etnología, edited by V. Durán and V. Cortegoso, pp. 163-184. Universidad Nacional de Cuyo, Mendoza.

Gil, A., M. Zárate, and G. Neme 2005. Mid-Holocene paleoenvironments and the archaeological record of southern Mendoza, Argentina. Quaternary International 132:81-94.

Glascock, M. and J. Ferguson 2009. X-ray Fluorescence Analysis of Obsidian Artifacts for a Study of Human Responses to Middle Holocene Climate Changes in Mendoza Province, Argentina. Report of Findings, Archaeometry Laboratory, Missouri University Research Reactor.

Hall, M. 1983. Late Holocene Hunter-Gatherers and Volcanism in the Long Valley-Mono Basin Region: Prehistoric Culture Change in the Eastern Sierra Nevada. Ph.D. dissertation, Department of Anthropology, University of California, Riverside.

Hocking, R. 1996. Methods and Applications of Linear Models: Regression and Analysis of Variance. John Wiley, New York.

Hughes, R. (ed.) 1984. Obsidian Studies in the Great Basin. University of California Archaeological Research Facility, Berkeley.

Hughes, R. (ed.) 1989. Current Directions in California Obsidian Studies. University of California Archaeological Research Facility, Berkeley.

Liritzis, I. 2006. SIMS-SS: A new obsidian hydration dating method: Analysis and theoretical principles. Archaeometry 48:538-547.

Liritzis, I. 2014. Obsidian Hydration Dating. In Encyclopedia of Scientific Dating Methods, edited by W.J. Rink and J.W. Thompson, pp.1-23. Springer-Verlag, Berlin.

Liritzis, I. and M. Diakostamatiou 2002. Towards a new method of obsidian hydration dating with secondary ion mass spectrometry via a surface saturation layer approach. Medierranean Archaeology and Archaeometry 2:3-20. 
Liritzis, I., M. Diakostamatiou, C.M. Stevenson, S.W. Novak, and I. Abdelrehim 2004. The dating of hydrated obsidian surfaces by SIMS-SS. Journal of Radioanalytical Nuclear Chemistry 261:51-60.

Liritzis, I. and N. Laskaris 2011. Fifty years of obsidian hydration dating in archaeology. Journal of Non-Crystalline Solids 357:2011-2023.

Meighan, C. 1978. Obsidian dating of the Malibu site. In Obsidian Dates II: A Compendium of the Obsidian Hydration Determinations Made at the UCLA Obsidian Hydration Laboratory, edited by C.W. Meighan and P.I. Vanderhoeven, pp. 158-161. University of California, Los Angeles.

Meighan, C. 1983. Obsidian Dating in California: Theory and Practice. American Antiquity 48:600-609.

Neme, G. and A. Gil 2012. El registro arqueológico del sur de Mendoza en perspectiva biogeográfica. In Paleoecología Humana en el Sur de Mendoza: Perspectivas Arqueológicas, edited by G. Neme and A. Gil, pp. 255-279. Sociedad Argentina de Antropología, Buenos Aires.

Pierce, K. and I. Friedman 2000. Obsidian hydration dating of quaternary events. In Quaternary Geochronology: Methods and Applications, edited by J. Noller, J. Sowers and W. Lettis, pp. 223-240. American Geophysical Union, Washington, D.C.

Riciputi, L., M. Elam, L. Anovitz, and D. Cole 2002. Obsidian diffusion dating by secondary ion mass spectrometry: A test using results from Mound 65, Chalco, Mexico. Journal of Archaeological Science 29:1055-1075.

Ridings, R. 1996. Where in the world does obsidian hydration dating work? American Antiquity 61:136-148.

Rogers, A. 2006. Induced hydration of obsidian: A simulation study of accuracy requirements. Journal of Archaeological Science 33:1696-1705.

Rogers, A. 2007. Effective hydration temperature of obsidian: A diffusion theory analysis of time-dependent hydration rates. Journal of Archaeological Science 34:656-665.

Rogers, A. 2008a. Obsidian hydration dating: Accuracy and resolution limitations imposed by intrinsic water variability. Journal of Archaeological Science 35:2009-2016.

Rogers, A. 2008b. Field data validation of an algorithm for computing obsidian effective hydration temperature. Journal of Archaeological Science 35:441-447.

Rogers, A. 2009. An estimate of Coso obsidian hydration rate, based on obsidian-radiocarbon pairings and the "weighted total least squares" method. International Association for Obsidian Studies Bulletin 41:9-20.

Rogers, A. 2010a. How did paleotemperature change affect obsidian hydration rates? Bulletin of the International Association for Obsidian Studies 42:13-20.

Rogers, A. 2010b. Accuracy of obsidian hydration dating based on obsidian-radiocarbon association and optical microscopy. Journal of Archaeological Science 37:3239-3246.
Rogers, A. and D. Duke 2011. An archaeologically validated protocol for computing obsidian hydration rates from laboratory data. Journal of Archaeological Science 38:1340-1345.

Rogers, A. and R. Yohe 2011. An improved equation for Coso hydration dating, based on obsidian-radiocarbon association. Society for California Archaeology Proceedings 25:1-15.

Salgán, L., R. Garvey, G. Neme, A. Gil, M. Giesso, M. Glascock, and V. Durán 2015. Las Cargas: Characterization and prehistoric use of a southern Andean obsidian source. Geoarchaeology 30:139-150.

Salgán, L., A. Gil, and G. Neme 2012. Obsidianas en la Payunia (sur de Mendoza, Argentina): Patrones de distribución e implicancias en la ocupación regional. Magallania 40: 259-273.

Salgán, L., A. Gil, and G. Neme 2014. Movilidad, aprovisionamiento y uso de obsidiana en el Payén, sur de la Provincia de Mendoza, Argentina. Comechingonia 18:33-50.

Stevenson, C., I. Abdelrehim, and S. Novak 2004. High precision measurement of obsidian hydration layers on artifacts from the Hopewell site using secondary ion mass spectrometry. American Antiquity 69:555-568.

Stevenson, C., W.P. Freeborn, and B. Scheetz 1987. Obsidian hydration dating: An improved optical technique for measuring the width of the hydration rim. Archaeometry 29:120-123.

Stevenson, C., M. Gottesman, and M. Macko 2000. Redefining the working assumptions of obsidian hydration dating. Journal of California and Great Basin Anthropology 22:223-236.

Stevenson, C., E. Knaus, J. Mazer, and J. Bates 1993. Homogeneity of water content in obsidian from the Coso Volcanic Field: Implications for obsidian hydration dating. Geoarchaeology 8:371-384.

Stevenson, C., T. Ladefoged, and S. Novak 2013. Prehistoric settlement chronology on Rapa Nui, Chile: Obsidian hydration dating using infrared photoacoustic spectroscopy. Journal of Archaeological Science 40:3021-3030.

Stevenson, C., I. Liritzis, M. Diakostamatiou, and S. Novak 2002. Investigations towards the hydration dating of Aegean obsidians. Mediterranean Archaeology and Archaeometry 2:93-100.

Stevenson, C., J. Mazer, and B. Scheetz 1998. Laboratory obsidian hydration rates: Theory, method, and application. In Archaeological Obsidian Studies: Method and Theory, Advances in Archaeological and Museum Science, Vol. 3., edited by M. S. Shackley, pp. 181-204. Plenum, New York.

Stevenson, C. and S. Novak 2011. Obsidian hydration dating by infrared spectroscopy: Method and calibration. Journal of Archaeological Science 38:1716-1726.

Stevenson, C. and A. Rogers 2014. Transient and equilibrium solubility of water in rhyolitic glass: Implications for hydration rate development at elevated temperature. Journal of Archaeological Science 45:15-19.

Thomas, D. 1981. How to classify the projectile points from Monitor Valley, Nevada. Journal of California and Great Basin Anthropology 3:7-43. 
